\title{
Production of exopolysaccharide by Rhizobium leguminosarum bv. trifolii and its role in bacterial attachment and surface properties
}

\author{
Monika Janczarek • Kamila Rachwał • Jolanta Cieśla • \\ Grażyna Ginalska $\cdot$ Andrzej Bieganowski
}

Received: 18 July 2014 / Accepted: 26 October 2014 /Published online: 12 November 2014

(C) The Auhtor(s) 2014. This article is published with open access at Springerlink.com

\begin{abstract}
Background and aims The acidic exopolysaccharide (EPS) produced by Rhizobium leguminosarum bv. trifolii is required for the establishment of effective symbiosis with compatible host plants (Trifolium spp.). In the rhizobium-legume interaction, early stages of root infection and nodule development have been well studied from a genetic standpoint. However, factors important for colonization of several surfaces by rhizobia,
\end{abstract}

Responsible Editor: Katharina Pawlowski.

M. Janczarek $(\bowtie) \cdot K$. Rachwał

Department of Genetics and Microbiology, Marie

Curie-Skłodowska University,

Akademicka 19, 20-033 Lublin, Poland

e-mail: mon.jan@poczta.umcs.lublin.pl

K. Rachwał

e-mail: rachwal.kamila@gmail.com

J. Cieśla · A. Bieganowski

Institute of Agrophysics, Polish Academy of Sciences,

P.O. Box 201, Doświadczalna 4, 20-290 Lublin, Poland

J. Cieśla

e-mail: j.ciesla@ipan.lublin.pl

A. Bieganowski

e-mail: a.bieganowski@ipan.lublin.pl

G. Ginalska

Chair and Department of Biochemistry and Biotechnology,

Medical University in Lublin,

Chodzki 1 st., 20-093 Lublin, Poland

e-mail: grazyna.ginalska@umlub.pl including soil particles and roots, have not yet been thoroughly investigated. The aim of this study was establishing of environmental factors affecting production of EPS by R. leguminosarum bv. trifolii strain 24.2 and the role of this polysaccharide in bacterial surface properties and attachment ability.

Methods Besides the wild-type strain, its derivatives differing in the level of EPS produced were used to these analyses. The ability of attachment to abiotic and biotic surfaces of these strains were established using CFU counting experiments. Three-dimensional structure and other parameters of biofilms formed were characterized in confocal laser scanning microscopy. Electrokinetic (zeta) potential of rhizobial cells were determined using Laser Doppler Velocimetry.

Results It was evidenced that the ability of $R$. leguminosarum bv. trifolii to produce EPS significantly affected bacterial attachment and biofilm formation on both abiotic and biotic surfaces. In addition, the presence of this polysaccharide influenced the zeta potential of rhizobial cells. Mutant strains having a mutation in genes involved in EPS synthesis were significantly impaired in attachment, whereas strains overproducing this polysaccharide showed higher adhesion efficiency to all of the tested materials. EPS facilitated attachment of bacterial cells to the tested surfaces most probably due to hydrophobic interactions and heterogeneity of the envelope surface.

Conclusions EPS produced by R. leguminosarum bv. trifolii plays a significant role in attachment and biofilm formation to both abiotic and biotic surfaces as well as bacterial surface properties. 
Keywords Rhizobium leguminosarum bv. trifolii . Exopolysaccharide production · pss $A$ and $\operatorname{rosR}$ genes . Biofilm formation $\cdot$ Root attachment $\cdot$ Zeta potential

\section{Introduction}

Rhizobium leguminosarum bv. trifolii is a nitrogenfixing bacterium that can either exist as a free-living organism in the soil or live in symbiotic association with clover (Trifolium spp.) (Fagerli and Svenning 2005; Duodu et al. 2009). The establishment of symbiosis is a complex process, which involves an exchange of many molecular signals between both the host plant and the microsymbionts; among them, flavonoids and bacterial lipo-chitooligosaccharides, called Nod factors, are the best characterized molecules (Broughton et al. 2003; Janczarek et al. 2014). Rhizobia are able to induce formation of nodules, specialized organs on roots and stems of legumes offering the bacteria an exclusive ecological niche in which they reduce atmospheric dinitrogen to ammonium. This form of nitrogen is then made available to the host plant, which in turn provides carbon sources to the microsymbiont (Martínez-Romero 2003; Oldroyd et al. 2011). Besides flavonoids and Nod factors, rhizobial acidic exopolysaccharides (EPS) play a significant role in the establishment of an effective symbiosis especially with legumes that form indeterminate-type nodules (e.g. clover, pea, vetch, and alfalfa) (Rolfe et al. 1996; Becker and Pühler 1998; Janczarek and Urbanik-Sypniewska 2013). This polysaccharide is indispensable for protection against host plant defence reactions and initiation and elongation of infection threads, special tubular structures via which rhizobia colonize root nodules (Cheng and Walker 1998; Workum et al. 1998; Jaszek et al. 2014). EPS-deficient mutant strains of $R$. leguminosarum bvs. trifolii and viciae, and Sinorhizobium meliloti induce formation of empty or only partially infected nodulelike structures on roots of compatible host plants that are ineffective in nitrogen fixation (Ivashina et al. 1994; Cheng and Walker 1998; Workum et al. 1998; Janczarek and Rachwał 2013). On the other hand, EPS-overproducing $R$. leguminosarum and S. meliloti strains are characterized by significantly enhanced occupancy of the host plant nodules and symbiotic effectiveness (Janczarek et al. 2009; Lehman and Long 2013). In free-living rhizobia, several other functions are also ascribed to this polysaccharide, including nutrient gathering, biofilm formation, and protection against desiccation and environmental stresses, which ensure adaptation of these bacteria to changing soil conditions (Broos et al. 2005; Janczarek 2011).

The chemical structure of EPS synthesized by $R$. leguminosarum has been determined in detail. This polymer is composed of octasaccharide repeating units which contain D-glucose, D-galactose, and Dglucuronic acid residues in a molar ratio 5:1:2, additionally modified with $O$-acetyl and pyruvyl groups (Robertsen et al. 1981; Philip-Hollingsworth et al. 1989; O’Neill et al. 1991; Breedveld et al. 1993). Also, a majority of the EPS synthesis pathway has been established in this bacterium and biological functions of several proteins have been experimentally confirmed. The biosynthesis of this heteropolymer in $R$. leguminosarum is conducted by a large multienzymatic complex located in the bacterial inner membrane. The synthesis of the EPS repeating units is initiated by an enzyme encoded by the pss $A$ gene which transfers UDP-glucose to an isoprenyl phosphate lipid carrier located in the inner membrane (Pollock et al. 1998). The second step of the unit synthesis is conducted by a glucuronosyl-( $\beta 1-4)$-glucosyl transferase PssDE, whereas a glucuronosyl-( $\beta 1-4)$-glucuronosyl transferase PssC catalyses the third step of this process. Based on sequence similarities of Pss proteins to enzymes available in databases and phenotypes of several pss mutants, Ivashina and Ksenzenko (2012) postulated that subsequent steps of the subunit assembly are carried out by PssS, PssF, Pssi/PssG and PssH/PssI glycosyltransferases, respectively. Moreover, other Pss proteins (PssR, PssM, and PssK) are most probably engaged in non-sugar modifications of EPS. Among them, a ketal pyruvate transferase PssM was found to be indispensable for addition of pyruvyl groups to the subterminal sugar residue in the repeating units (Ivashina et al. 2010).

The biosynthesis of EPS in rhizobia is a complex process influenced by several stress and nutrition factors, which to date have been studied most extensively in S. meliloti. Soil conditions such as availability of nitrogen, phosphate, and sulphur, and osmotic pressure affect EPS production in this bacterium (for details see review of Janczarek 2011). In contrast to S. meliloti, the knowledge of the influence of environmental factors on EPS production in $R$. leguminosarum and its role in bacterial surface properties are still scarce. Up to now, it was evidenced that phosphate and clover root 
exudates affect the level of EPS synthesis in this rhizobial species (Janczarek and Skorupska 2011).

The aim of this study was to establish environmental factors affecting production of EPS by R. leguminosarum bv. trifolii 24.2 and the role of this polysaccharide in bacterial surface properties and attachment ability to both biotic and abiotic surfaces. This was evaluated using, apart from the wild-type strain, its genetically modified derivatives differing in the level of EPS produced (EPS-deficient and EPS-overproducing strains).

\section{Materials and methods}

Strains, media, and growth conditions

Bacterial strains used in this study are listed in Table 1. R. leguminosarum bv. trifolii wild-type strain Rt24.2, pssA (Rt5819) and rosR (Rt2472) mutants, and Rt24.2(pBA1) and Rt24.2(pBR1) derivatives carrying additional copies of these genes were grown in 79CA medium with $1 \%$ glycerol as a carbon source at $28{ }^{\circ} \mathrm{C}$ (Vincent 1970). When required, antibiotics were used at the following final concentrations: kanamycin $40 \mu \mathrm{g} \mathrm{mL}^{-1}$, nalidixic acid $20 \mu \mathrm{g} \mathrm{mL} \mathrm{m}^{-1}$, and rifampin $40 \mu \mathrm{g} \mathrm{mL}^{-1}$. To study the influence of various carbon sources on the growth of the Rt24.2 strain and its efficiency in EPS production, a $1 \%$ concentration of these compounds and a 72-h time of growth were used. In order to establish the effect of $\mathrm{pH}$ on the growth and the level of EPS produced by Rt 24.2 after $72 \mathrm{~h}$, a set of 79CA media with $\mathrm{pH}$ ranging from 3 to 10 was tested. To study whether $\mathrm{Na}^{+}, \mathrm{Mg}^{2+}$, and $\mathrm{Ca}^{2+}$ ions affect Rt24.2 growth and EPS synthesis, a defined M1 minimal medium was used containing $1 \%$ glycerol, $2 \mathrm{ml} \mathrm{L}^{-1}$ vitamin stock solution, and either $40 \mathrm{mM} \mathrm{NaCl}, 80 \mathrm{mM}$

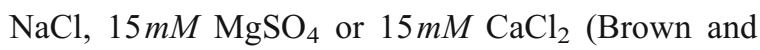
Dilworth 1975; Sambrook et al. 1989). The standard M1 medium containing $1.7 \mathrm{mM} \mathrm{NaCl}$ and $1 \mathrm{mM}$ $\mathrm{MgSO}_{4}$ was used as a control medium.

EPS isolation and quantification

EPS was isolated and quantified as described previously (Janczarek and Urbanik-Sypniewska 2013). Briefly, bacteria were grown in appropriate 79CA medium for up to 4 days at $28^{\circ} \mathrm{C}$ in a rotary shaker $(160 \mathrm{rpm})$. Then, the optical density $\mathrm{OD}_{600}$ of the cultures was measured and culture supernatants were used for EPS precipitation with $96 \%$ cold ethanol (1:4 vol/vol). Subsequently, EPSs were collected by centrifugation (20 min, 14 $000 \mathrm{rpm}$ ), and after re-dissolving in deionized water analysed for carbohydrates according to Loewus (1952). The total sugar content was calculated as glucose equivalents per unit of $\mathrm{OD}_{600}$. Each experiment was repeated three times with three biological repetitions for each treatment.

Characterization of rhizobial biofilms in confocal laser scanning microscopy

In order to characterize the three-dimensional structure and other parameters of biofilms formed by $R$. leguminosarum strains in polystyrene microplate wells, an Olympus SV1000 microscope was used. Bacteria present in the biofilms were stained with the LIVE/DEAD BacLight ${ }^{\mathrm{TM}}$ kit (Invitrogen), which contains two dyes Syto-9 and propidium iodide and facilitates determination of the ratio of live (stained with Syto-9) to dead (stained with propidium iodide) cells (Leuko et al. 2004). For this purpose, 24-h bacterial cultures in 79CA were equilibrated to $\mathrm{OD}_{600}=0.6$ and subsequently diluted 1000-fold in the same medium.

Table 1 Bacterial strains used in this study

\begin{tabular}{|c|c|c|}
\hline Strains & Relevant characteristics & Reference \\
\hline Rt24.2 & Wild type, $\mathrm{Rif}^{\mathrm{R}}, \mathrm{Nx}^{\mathrm{R}}$ & Janczarek et al. 2009 \\
\hline Rt5819 & Rt24.2 derivative carrying a mini-Tn 5 transposon in $p s s A$ gene, $\mathrm{Rif}^{\mathrm{R}}, \mathrm{Km}^{\mathrm{R}}$ & Janczarek et al. 2009 \\
\hline Rt2472 & Rt24.2 derivative carrying a mini-Tn5 transposon in $\operatorname{ros} R$ gene, $\mathrm{Rif}^{\mathrm{R}}, \mathrm{Km}^{\mathrm{R}}$ & Janczarek et al. 2009 \\
\hline Rt24.2(pBA1) & Rt24.2 derivative carrying additional copies of $p s s A$ gene on pBBR1MCS-2 vector, $\operatorname{Rif}^{\mathrm{R}}, \mathrm{Km}^{\mathrm{R}}$ & Janczarek et al. 2009 \\
\hline Rt24.2(pBR1) & Rt24.2 derivative carrying additional copies of $\operatorname{ros} R$ gene on pBBR1MCS-2 vector, $\mathrm{Rif}^{\mathrm{R}}, \mathrm{Km}^{\mathrm{R}}$ & Janczarek et al. 2009 \\
\hline
\end{tabular}

$\mathrm{Rif}^{\mathrm{R}}$ rifampin resistance, $\mathrm{Nx}^{\mathrm{R}}-$ nalidix acid resistance, $\mathrm{Km}^{\mathrm{R}}-$ kanamycin resistance 
$100-\mu 1$ aliquots were added to each well and left to growth for up to 4 days at $28^{\circ} \mathrm{C}$ under static conditions. After 4 days, the contents of the wells were removed and each well was washed 3 times with $200 \mu \mathrm{l}$ of $0.85 \%$ $\mathrm{NaCl}$ and stained with $0.85 \% \mathrm{NaCl}$ containing $5 \mu M$ Syto-9 and $30 \mu M$ propidium iodide for $30 \mathrm{~min}$. Next, the dyes were removed and the wells were washed 3 times with $0.85 \% \mathrm{NaCl}$ and observed under the microscope. For each strain, the experiment was repeated two times with three growth cultures per individual strain and three wells per each culture. In order to establish the ratios of live/dead cells in the biofilm formed by the individual strain, two independent sets of images obtained separately for green (Syto-9) and red (propidium iodide) fluorescence were collected from 9 wells. These were a set of 45 images obtained for green fluorescence (live cells) and a set of 45 images obtained for red fluorescence (dead cells) from the same parts of the biofilms. The biofilm images presented in Fig. 3 are composed of both overlapping images with green and red fluorescence.

In addition, the images of the biofilms stained with Syto-9 were analysed to characterize other morphological parameters. The ratio of live to dead cells, the percentage of the area covered by the biofilm, length of coastline, and fractal dimension were calculated using ImageJ 1.43e software (Wayne Rasband, NIH, USA) (Beyenal and Lewandowski 2004; Ploux et al. 2007). Three-dimensional images were reconstructed using a Laser Scanning Confocal Microscope LSC 5 PASCAL (Carl Zeiss, Germany) with 200x magnification.

\section{Sand assays}

The assay of rhizobial cell attachment to quartz sand was performed according to Fujishige et al. (2006a; 2006b) with some modifications. Briefly, rhizobial strains were grown in 79CA medium containing $1 \%$ glycerol at $28^{\circ} \mathrm{C}$ for $24 \mathrm{~h}$. For the Rt24.2(pBR1) and Rt24.2(pBA1) strains, kanamycin $\left(20 \mu \mathrm{g} \mathrm{mL}^{-1}\right)$ was added into the medium. Then, the bacterial cultures were centrifuged (10 $\mathrm{min}, 8,000 \mathrm{rpm})$, washed, and diluted in the same medium to $\mathrm{OD}_{600}=0.2\left(\mathrm{ca} .2 \times 10^{8}\right.$ cells $\left.\mathrm{mL}^{-1}\right) .500 \mu \mathrm{l}$ of the bacterial suspension was added into an Eppendorf tube containing $150 \mathrm{mg}$ of sterile sand or the same volume of the medium only as a control. The tubes were left horizontally at $28^{\circ} \mathrm{C}$ for 1 and $48 \mathrm{~h}$. Next, the probes were shortly centrifuged (30 s, 2,000 rpm), the liquid was removed, and the sand was 3 times washed with $10 \mathrm{mM} \mathrm{MgSO}$ and extensively vortexed to dissociate cells from the sand particles. Finally, $1 \mathrm{ml}$ 79CA was added to each probe and serial dilutions were made in this medium. $100-\mu$ l aliquots were placed on plates with 79CA agar (with kanamycin when required) to obtain CFUs (values of CFU were normalized per $\mathrm{mg}$ of sand). The experiment was performed in triplicate with three biological repetitions for each tested strain.

\section{Attachment assay of rhizobia to clover roots}

The wild-type strain Rt24.2 and its derivatives (Rt2472, Rt5819, Rt24.2(pBR1) and Rt24.2(pBA1)) were used to establish the ability of rhizobial strains to attach to clover roots. For this experiment, the method described by Fujishige et al. (2006a) was applied with a slight modification. Suspensions of rhizobial strains were made in Fåhraeus liquid medium with $\mathrm{OD}_{600}=0.1$. Roots of 3-day-old clover seedlings were dipped into the bacterial suspensions for $1 \mathrm{~h}$ or incubated for $48 \mathrm{~h}$ (100 $\mu \mathrm{l}$ of bacterial suspension per seedling). Then, the plants were placed on sterile Whatman paper to remove the excess liquid. Next, the roots were washed overnight with $0.05 \%$ Tween-20 on a rocking platform shaker (100 rpm) to remove loosely associated bacteria, and weighed after removing the excess liquid. To establish the number of bacteria attached to the root surface, each seedling was homogenized in $300 \mu$ l of sterile water. The homogenates obtained were shortly centrifuged (30 s, 8,000 rpm), serially diluted in water, and 100- $\mu \mathrm{l}$ aliquots were placed on 79CA plates for colony counting. The experiment was repeated three times and 10 seedlings per individual strain were used in each repetition.

Determination of the electrokinetic potential of rhizobial strains using Laser Doppler Velocimetry

To determine whether EPS produced by rhizobia affects surface electrical properties of their cells, the electrokinetic (zeta) potential of the bacterial cultures was determined by means of a Zetasizer Nano ZS device (Malvern, UK). The methodology used in this study was consistent with that presented in the paper by Cieśla et al. (2011). The zeta potential values were calculated by the software on the basis of the Henry equation with the use of the Smoluchowski approximation (Delgado et al. 2007; Wilson et al. 2001). All 
measurements were done at $20{ }^{\circ} \mathrm{C}( \pm 0.1)$. For this experiment, 24-h bacterial cultures of the five rhizobial strains (Rt24.2, Rt2472, Rt5819, Rt24.2(pBA1), and Rt24.2(pBR1)) grown in 79CA medium were used. Optical density $\left(\mathrm{OD}_{600}\right)$ of the cultures was measured and equilibrated to about 0.4 using fresh portions of 79CA medium. In addition, 24-, 48-, and 96-h cultures of the Rt24.2 strain were used. Both these experiments were repeated three times and nine independent measurements were done for each strain.

Because the zeta potential strongly depends on bacterial culture density (Cieśla et al. 2011), the results presented in this work were expressed as relative zeta potential. It was obtained by dividing the value of the zeta potential by optical density $\left(\mathrm{OD}_{600}\right)$ of the individual bacterial suspension.

\section{Statistical analysis}

The results are mean \pm SD from three experiments performed in triplicate. Comparison of values between different bacterial strains in the same conditions was performed using a one-way ANOVA to find statistically significant differences. In cases where the null hypothesis (all population means are equal) was rejected at the alpha $=0.05$ level, the Tukey's HSD (Honestly Significant Difference) test was applied. Significant differences among the treatments or the tested strains were considered at the level of $p$ values $<0.05$.

\section{Results}

Factors influencing the bacterial growth rate and production of exopolysaccharide in R. leguminosarum bv. trifolii

Extracellular polysaccharide secreted by $R$. leguminosarum bv. trifolii into the environment plays an essential role in the symbiotic interaction of this bacterium with its host plant, i.e. the clover (Trifolium pratense). Therefore, we decided to establish which environmental factors affect the production of this polysaccharide in $R$. leguminosarum bv. trifolii. Different parameters, such as the type of the carbon source, time of bacterial growth, temperature, $\mathrm{pH}$, and some cations $\left(\mathrm{Na}^{+}, \mathrm{Mg}^{2+}\right.$ and $\left.\mathrm{Ca}^{2+}\right)$ were examined using a well-characterized strain Rt24.2, which belongs to this biovar.
At first, the influence of the type of the carbon source on both the bacterial growth rate and efficiency of EPS synthesis was studied. Among the tested compounds, glycerol proved to be the best carbon source for the growth of the analysed strain (Fig. 1). A high level of growth was also observed in the presence of maltose, sucrose, mannitol, mannose, glucose, galactose and sorbitol, whereas the level of utilization of the remaining tested compounds was significantly lower. Moreover, Rt24.2 produced the highest amount of EPS in the presence of glycerol. Also, other compounds, like sorbitol, glucose, succinate, mannitol, and glucosamine were carbon sources, in the presence of which high levels of EPS were synthesized by this strain. Based on the presented data, it may be noticed that the levels of EPS synthesis correlated with bacterial culture density under several growth conditions. This was observed for such carbon sources as for example glycerol, glucose, sorbitol, rhamnose, and glucosamine. On the other hand, although strain Rt24.2 effectively used some carbon sources for the growth (maltose, lactose, mannitol, mannose), the production of EPS by this bacterium in the presence of these compounds persisted at relatively low levels. An opposite situation was observed for succinate. Culture density in the presence of this carbon source was very low but the amount of EPS synthesized was high. These results indicate complex regulation of the process of EPS synthesis in rhizobia, in which carbon sources and their metabolism are probably engaged.

In summary, since glycerol proved to be the best carbon source for both the bacterial growth and EPS production, this compound was used in all further experiments.

The next parameter tested was the time of bacterial growth. For this purpose, a time-course experiment was performed, in which the Rt24.2 growth and efficiency of EPS synthesis were determined after 24, 48, 72 and $96 \mathrm{~h}$. The growth kinetics and amounts of EPS produced by this bacterium are shown in Fig. 2a. The Rt24.2 strain grew effectively in the tested culture medium and reached a stationary phase after $72 \mathrm{~h}$. Further incubation time did not affect the density of the bacterial cultures. It was observed that the Rt24.2 strain synthesized high amounts of EPS during the tested time periods, and the highest level of the synthesis was achieved after $72 \mathrm{~h}$ of growth (Fig. 2a). The longer incubation time ( $96 \mathrm{~h}$ ) did not significantly increase the amount of EPS produced. Therefore, the 72-h incubation time was used in further experiments. 


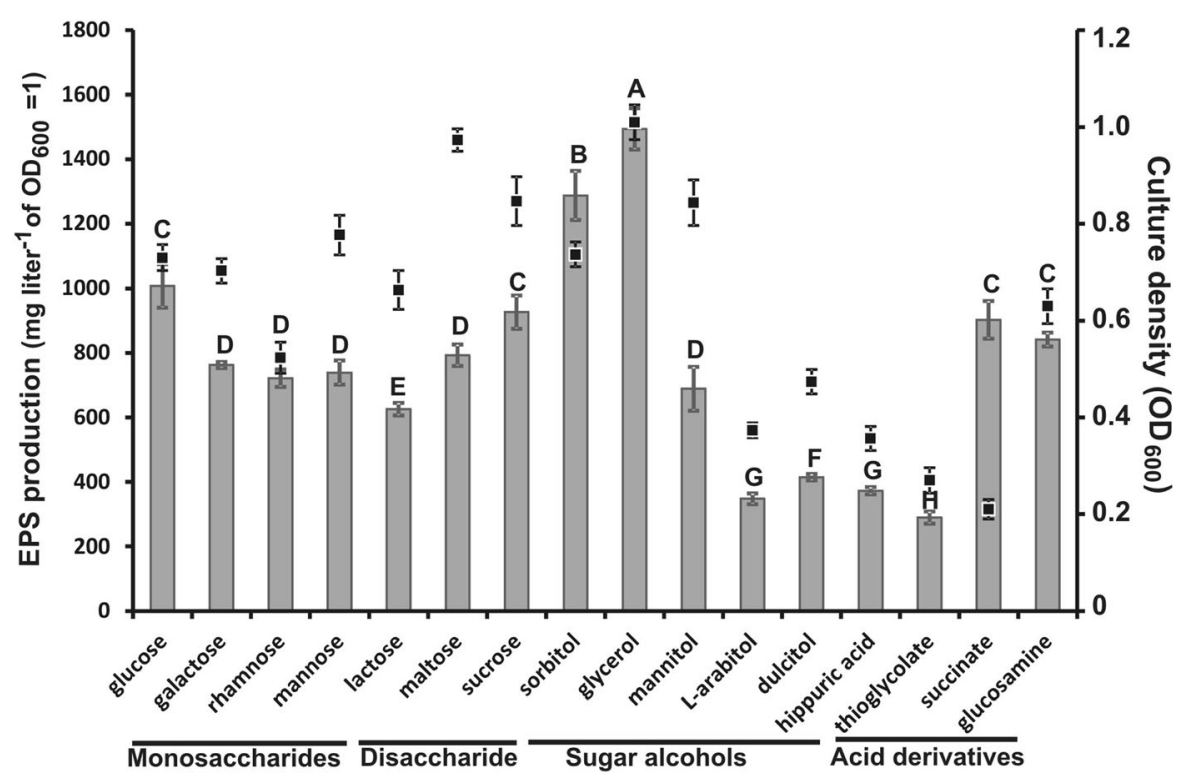

Fig. 1 Effect of various carbon sources on the growth and exopolysaccharide production in $R$. leguminosarum bv. trifolii 24.2. Optical densities $\left(\mathrm{OD}_{600}\right)$ of growth cultures are presented as black squares and amounts of EPS produced by the Rt 24.2 strain in the presence of particular carbon sources are shown as

In addition, the influence of temperature on the bacterial growth and efficiency of EPS production was examined. For this purpose, the Rt24.2 strain bacteria were grown at various temperatures $\left(20-30{ }^{\circ} \mathrm{C}\right)$ for 3 days and then culture densities and amounts of synthesized EPS were established (Fig. 2b). Among the tested conditions, the range of $24-28{ }^{\circ} \mathrm{C}$ was optimal for both the growth rate and efficiency of EPS synthesis. At a higher temperature $\left(30{ }^{\circ} \mathrm{C}\right)$, the bacterial growth and the level of produced EPS decreased significantly. Interestingly, although the low temperature $\left(20^{\circ} \mathrm{C}\right)$ reduced the growth rate most significantly among all of the tested conditions, the production of EPS was not substantially decreased. These results indicate that the temperature required for the highest production of EPS by the Rt24.2 strain is similar to that for its optimal growth.

The next growth parameter analysed was the $\mathrm{pH}$ of the medium. The range of the $\mathrm{pH}$ tested was from 3 to 10 (Fig. 2c). Under the conditions used, Rt24.2 proved to be able to grow efficiently at $\mathrm{pH}$ from 7 to 8 , and the optimal growth of this strain was achieved at $\mathrm{pH} 7.5$. At a $\mathrm{pH}$ lower than 6.5 and higher than 8 , the bacteria grew very poorly and the cultures reached only low optical density even after 72-h growth. Considering EPS production, the optimal level of synthesis of this polymer grey columns. The presented data are mean \pm SD for three independent experiments. Statistically significant differences in the amounts of produced EPS ( $p<0.05$; ANOVA, post hoc Tukey's test) are marked with different letters

was obtained at $\mathrm{pH}$ range from 7 to 9 with the highest amounts obtained at $\mathrm{pH} 7.5$. These data indicate that the $\mathrm{pH}$ range for high production of EPS by the Rt 24.2 strain is larger than that required for the optimal bacterial growth.

Moreover, the influence of several ions $\left(\mathrm{Na}^{+}, \mathrm{Mg}^{2+}\right.$, and $\mathrm{Ca}^{2+}$ ) on the Rt24.2 growth and efficiency of EPS synthesis was studied. It was observed that the tested concentrations of these ions did not significantly affect the bacterial growth (with the exception of $80 \mathrm{mM} \mathrm{NaCl}$ ) (Fig. 2d). In relation to EPS synthesis, $\mathrm{Mg}^{2+}$ and $\mathrm{Ca}^{2+}$ ions at $15 \mathrm{mM}$ concentrations slightly decreased the amount of produced EPS, but the differences observed were not statistically significant. In contrast, the presence of $\mathrm{NaCl}$, especially at the $80 \mathrm{mM}$ concentration, decreased not only the bacterial growth, but also the level of synthesized EPS.

In conclusion, all the presented data indicate that multiple factors affect EPS production in $R$. leguminosarum bv. trifolii, including the type of the carbon source, temperature, $\mathrm{pH}$, and the age of the bacterial culture. For the Rt24.2 strain, the highest level of EPS production was observed in the presence of glycerol as the carbon source, at the temperature range $24-28{ }^{\circ} \mathrm{C}, \mathrm{pH} 7.5$, and the stationary growth phase (72-96 h). 


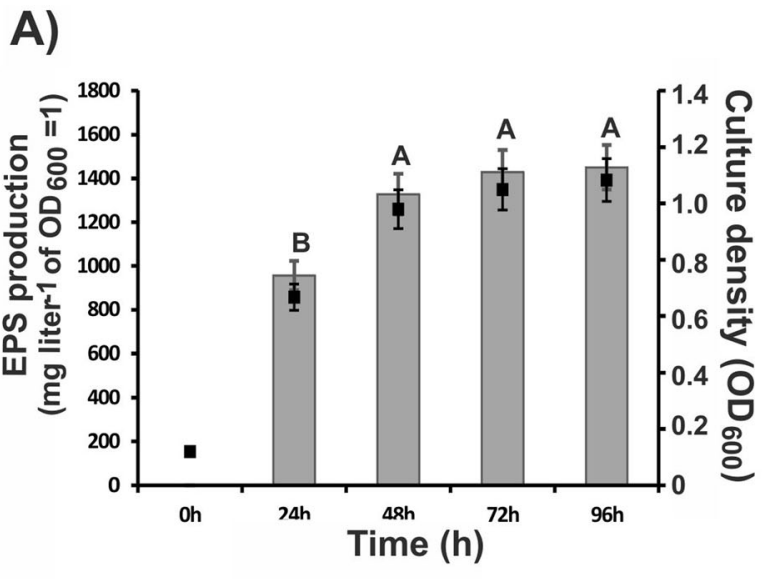

C)

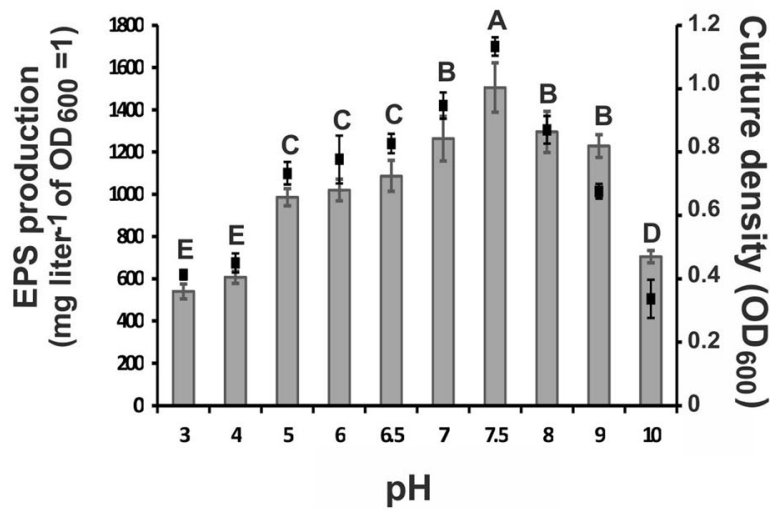

Fig. 2 The influence of different factors on the growth and exopolysaccharide production in $R$. leguminosarum bv. trifolii 24.2: $\mathbf{a}$ the age of the cultures, $\mathbf{b}$ temperature, $\mathbf{c} \mathrm{pH}$ and $\mathbf{d}$ ions. Optical densities $\left(\mathrm{OD}_{600}\right)$ of growth cultures are marked as black squares, whereas amounts of EPS synthesized by the Rt24.2 strain

Attachment and biofilm formation by rhizobial strains on abiotic surfaces

Literature data concerning various bacterial species provide evidence that extracellular polysaccharides play a significant role in biofilm formation as an essential component of the biofilm matrix (Rudrappa et al. 2008; Rinaudi and Giordiano 2010; Koo et al. 2013). Therefore, we decided to establish how the level of EPS production affects attachment and biofilm formation by R. leguminosarum bv. trifolii cells. In these experiments, strains differing in the amounts of synthesized EPS were used. Besides the wild-type strain Rt24.2, two mutant strains (Rt5819pss A and Rt2472rosR) having mutations in genes involved in EPS synthesis and regulation of this process, respectively, were included (Janczarek et al.
B)

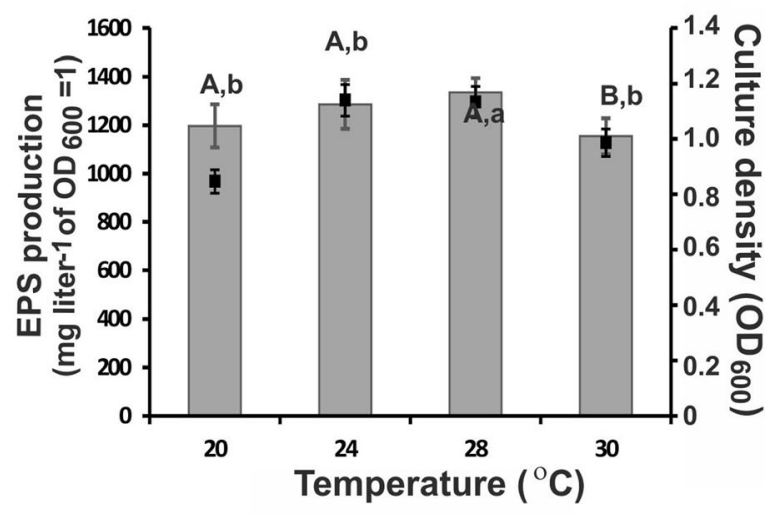

D)

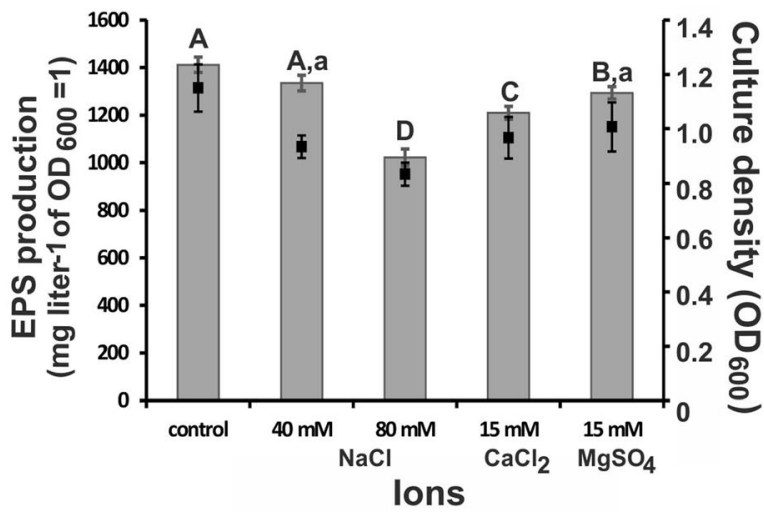

in the presence of particular carbon sources are shown as grey columns. The data are mean $\pm \mathrm{SD}$ for three independent experiments. Statistically significant differences in the amounts of EPS $(p<0.05$; ANOVA, post hoc Tukey's test) are marked with different letters

2009). The Rt5819 strain with a mutation in the pss A gene encoding an enzyme involved in the first step of EPS synthesis is totally defective in production of this polymer. The second mutant Rt2472, which have a mutation in the ros $R$ gene encoding a positive regulator of EPS synthesis, produces a 3-fold lower amount of EPS than the wild-type strain. Moreover, two Rt24.2 derivatives obtained previously (Janczarek et al. 2009), which have additional copies of the pss $A$ and $\operatorname{ros} R$ genes on plasmids and overproduce EPS (from 156 to $168 \%$ of the wild-type level, respectively), were studied.

At first, the ability of attachment and biofilm formation by the R. leguminosarum bv. trifolii wild-type and its derivatives were tested in a time-course experiment using abiotic surfaces. To determine how different levels of EPS produced by the tested strains affect biofilm 
formation and its structure, the growth of the wild-type bacteria, mutants with disturbances in EPS synthesis, and EPS-overproducing strains was analysed in 79CA medium in a microtiter plate assay. For visualization of bacteria, their viability, and organization of formed biofilms, two fluorescent dyes specific for either live (SYTO-9) or dead (propidium iodide) cells, respectively, were used. After a 4-day experiment, the wild-type strain formed a typical mature biofilm with water channels on plastic surfaces, which showed regular and similar depth (on average $43 \mu \mathrm{m}$ ) on the whole space (Fig. 3, Table 2). In contrast, the biofilm organization and numbers of adherent bacteria differed essentially between the wild-type strain and the mutants after 4 days of incubation. Especially in the case of the pss A mutant, only rarely attached bacterial cells were present, and not the whole surface was covered by the biofilm. In addition, this immature and irregular pseudo-biofilm did not exceed the depth of $12.5 \mu \mathrm{m}$. Also, adhesion of the rosR mutant cells was significantly impaired and only immature biofilm with the maximal depth $21.6 \mu \mathrm{m}$ was formed. On the other hand, both Rt24.2 derivatives producing significantly more EPS than the wild-type bacteria formed huge amounts of mature and highly organized biofilms (Fig. 3). This was especially visible in the case of the Rt24.2(pBA1) strain carrying multiple pss $A$ copies. The bacteria were densely packed in the biofilm, which exhibited a nearly 3-fold greater depth than that formed by the wild-type (Table 2). Also, the values of other biofilm parameters (outline, maxima, and area covered by the biofilm) were significantly higher for the EPS-overproducing strains and substantially lower for both mutants in comparison to the wildtype strain.

Moreover, survival of bacteria in the biofilms formed by the individual strains was established and presented as a ratio of live to dead cells. We observed that this parameter differed essentially between the analysed strains (Table 2). In the 4-day-old biofilm formed by the wild-type bacteria, a majority of cells were alive (a live/dead ratio=49). Interestingly, this parameter was much lower for both EPS-deficient mutants. The decrease in cell viability was the highest in the pss $A$ mutant, which does not produce any amount of EPS (a ratio of 1.68). This indicates that the lack of proper amounts of EPS significantly reduced survival of the cells. In contrast, the live/dead ratios increased in the EPS-overproducing strains. This suggests that larger amounts of EPS secreted by the bacteria into the environment enable them to form biofilm with an appropriate organization faster and survive better in this specific ecological niche. All these data indicate that the EPS surrounding rhizobial cells and the level of production thereof play a crucial role in biofilm formation and bacterial survival.

Attachment of rhizobial strains to sand and clover roots

In the absence of compatible host plants, $R$. leguminosarum bv. trifolii has to survive long periods of time under soil conditions. Therefore, it seemed important to determine the attachment and biofilm forming ability of the wild-type strain Rt24.2 and its derivatives on surfaces such as quartz sand and host plant roots. Quartz sand was chosen because it is a natural environment for many soil bacteria including rhizobia, and also because it is less complex than soil, thereby allowing us to establish the attachment potential of the tested strains in a defined, but still natural material. In this experiment, the wild-type bacteria exhibited high efficiency in attachment to sand particles, since $3.4 \times 10^{4}$ cells per $1 \mathrm{mg}$ of sand were attached after $1 \mathrm{~h}$ and $16.5 \times 10^{4}$ cells within $48 \mathrm{~h}$ post inoculation (Fig. 4). In contrast, the $\operatorname{ros} R$ mutant showed a decreased ability to adhere to this material, since the numbers of the cells attached after 1-h and 48-h incubation were 33.5 and $38.4 \%$, respectively, of those attached by the wild-type strain. In the case of the pss $A$ mutant, an even stronger negative effect was observed. This strain almost totally lost the ability of attachment and biofilm formation on this surface, since only few cells were adherent to sand particles after 1-h incubation and they accounted for $7.6 \%$ of those detected for the control strain. On the other hand, the Rt24.2(pBA1) and Rt24.2(pBR1) strains secreting more EPS than the wild-type bacteria exhibited significantly higher efficiency in adhesion (Fig. 4). This was detected especially after $48 \mathrm{~h}$ of the experiment, when the numbers of the adherent bacteria were more than 2.5 -fold higher than those of the wild-type. These data indicate that EPS occurring outside of the rhizobial cells is very important for successful and efficient adhesion of the bacteria to surfaces present in the environment.

Rhizobia interact with compatible legume host plants in the soil in order to establish symbiosis. The first step of this interaction is attachment to and biofilm formation on the host root surface including root hairs, which are a target for initiation of legume infection. Therefore, we decided to determine ability of the $R$. leguminosarum 
Fig. 3 The structure of biofilms formed by the R. leguminosarum bv. trifolii wild-type strain 24.2 and its derivatives after 4 days. a The first vertical panel presents images of 4-day-old biofilms, with live (SYTO-9, green

fluorescence) and dead (propidium iodide, red fluorescence) cells. The insets show details of the structure of the particular biofilms. b The crosssections of the formed biofilms (they are presented as a bright part of the images)

\section{$\begin{array}{lll}\text { A) 4-day biofilm } & \text { B) cross section }\end{array}$}
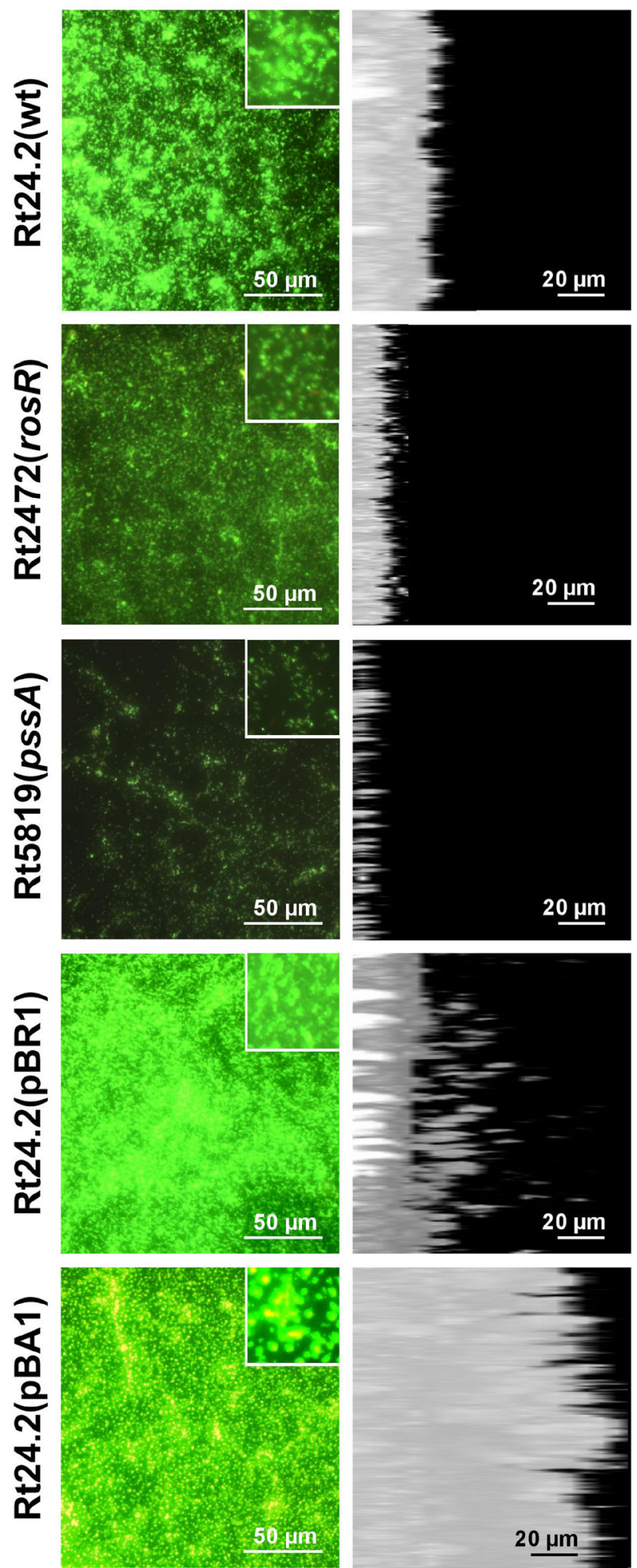
Table 2 Different parameters of 4-day-old biofilms formed by R. leguminosarum bv. trifolii wild-type strain Rt24.2 and its derivatives

\begin{tabular}{lccccc}
\hline Strain & Ratio of live/dead cells*1 & Depth of biofilm* $(\mu \mathrm{m})$ & $\begin{array}{l}\text { Area covered by } \\
\text { biofilm* }(\%)\end{array}$ & Maxima* (scalar units) & Outline* $\left(\mathrm{x} 10^{3}\right)(\mu \mathrm{m})$ \\
\hline Rt24.2 (wt) & $49.22 \pm 5.52^{\mathrm{B}}$ & $43.2 \pm 3.8^{\mathrm{C}}$ & $89.7 \pm 7.9^{\mathrm{A}}$ & $5023 \pm 899^{\mathrm{B}}$ & $118.4 \pm 8.2^{\mathrm{B}}$ \\
Rt2472 rosR & $24.45 \pm 4.71^{\mathrm{C}}$ & $21.6 \pm 2.7^{\mathrm{D}}$ & $48.72 \pm 6.1^{\mathrm{B}}$ & $2172 \pm 422^{\mathrm{C}}$ & $65.6 \pm 5.3^{\mathrm{C}}$ \\
Rt5819 pss $A$ & $1.68 \pm 0.19^{\mathrm{D}}$ & $12.5 \pm 1.6^{\mathrm{E}}$ & $29.15 \pm 3.1^{\mathrm{C}}$ & $1272 \pm 425^{\mathrm{D}}$ & $42.6 \pm 8.3^{\mathrm{D}}$ \\
Rt24.2(pBR1) & $143.2 \pm 36.2^{\mathrm{A}}$ & $72.9 \pm 8.8^{\mathrm{B}}$ & $96.69 \pm 8.9^{\mathrm{A}}$ & $6086 \pm 1064^{\mathrm{B}}$ & $230.1 \pm 22.7^{\mathrm{A}}$ \\
Rt24.2(pBA1) & $51.83 \pm 6.42^{\mathrm{B}}$ & $126.9 \pm 11.1^{\mathrm{A}}$ & $100 \pm 0^{\mathrm{A}}$ & $10137 \pm 1894^{\mathrm{A}}$ & $266.9 \pm 34.3^{\mathrm{A}}$ \\
\hline
\end{tabular}

*A, B, C, D, E - Within the same column, means followed by different letters are significantly different at $p<0.05$, ANOVA, post hoc Tukey's test

${ }^{1}$ Ratios of live to dead cells were calculated using two independent sets of images separately obtained for green (Syto-9) and red (propidium iodide) fluorescence, respectively

bv. trifolii wild-type strain as well as its EPS-deficient and EPS-overexpressing derivatives to adhere to clover roots. In this experiment, it was observed that the wildtype Rt24.2 attached with high efficiency to the host roots after the first hour of the experiment, and further incubation still continually increased the number of bacteria attached (Fig. 5). Also in this assay, the pss A mutant Rt5819 exhibited a lowest adhesion ability, among all the analysed strains. A very low number of bacteria were attached to the host roots $1 \mathrm{~h}$ post inoculation (they constituted less than $5 \%$ of the number of wild-type cells attached). Also, the rosR mutant Rt 2472 showed a decreased ability to adhere to the root surface, but this effect was not as high as that observed for the pssA mutant. On the other hand, both EPSoverproducing strains Rt24.2(pBA1) and Rt24.2(pBR1) showed more efficient attachment to clover roots in comparison to the wild-type bacteria (Fig. 5). The same tendency and similar differences in the adhesion ability between the tested strains were also observed after 48-h incubation. The above results confirm the crucial role of EPS in attachment and biofilm formation on the tested surfaces by $R$. leguminosarum bv. trifolii cells and indicate that the lack of this polysaccharide or its insufficient amount result in essential disturbances in these processes.

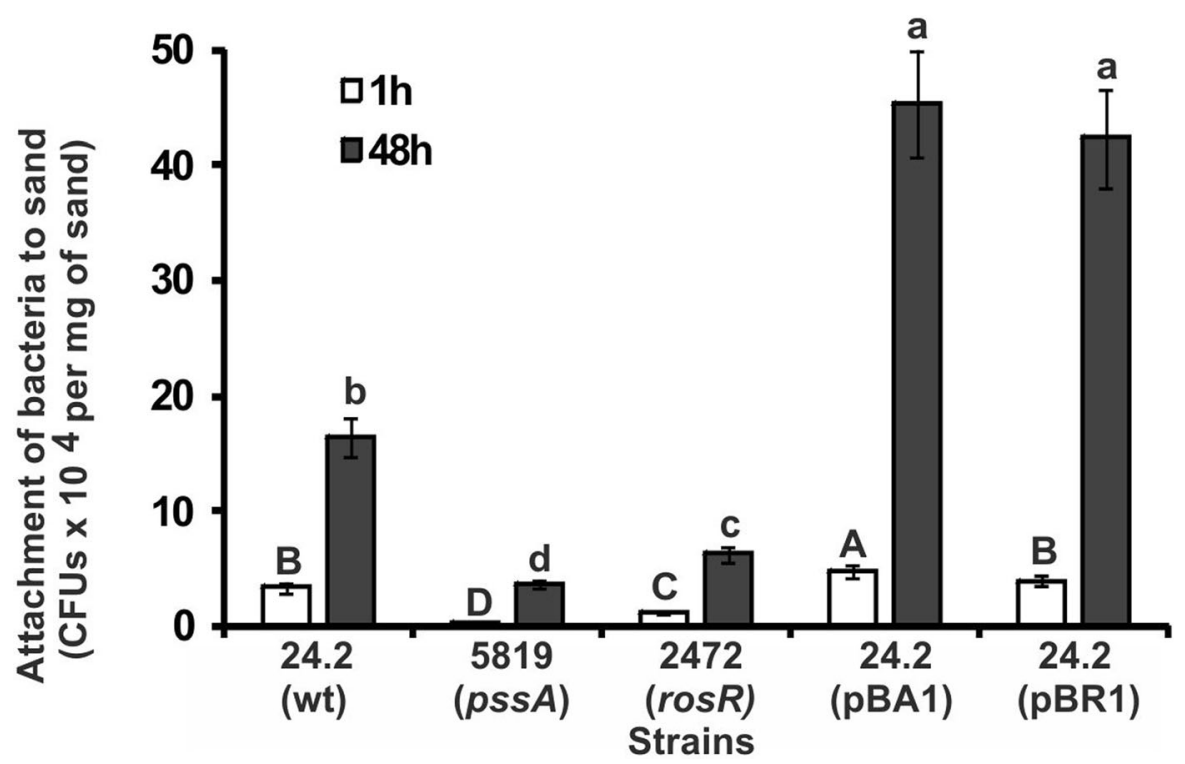

Fig. 4 Attachment of the R. leguminosarum bv. trifolii wild-type strain 24.2 and its derivatives to sand particles observed after $1 \mathrm{~h}$ and $48 \mathrm{~h}$ post inoculation. The presented data are mean \pm SD for three independent experiments. Statistically significant differences

$(p<0.05)$ observed between the strains after the 1-h experiment are marked with different upper case letters, whereas statistically significant differences $(p<0.05)$ observed after $48 \mathrm{~h}$ are marked with different lower case letters 
Surface properties of rhizobial strains determined using the electrokinetic potential

To characterize the surface properties of the five rhizobial strains, a relative electrokinetic potential was applied.

In general, the relative electrokinetic potential values were negative and strain-specific $(\mathrm{F}(4,40)=152$; $p<0.05)$. The Rt24.2 strain and its EPS-producing derivatives showed strong negative zeta potential values $($ Rt24.2 $=-63.5 \mathrm{mV} \pm 4.14$, Rt24.2(pBA1) $=-64.3 \mathrm{mV} \pm$ $3.58, \mathrm{Rt} 24.2(\mathrm{pBR} 1)=-58.8 \mathrm{mV} \pm 3.21)$. In contrast, the non-mucoid Rt5819 strain showed the highest value of the zeta potential $(-32.1 \mathrm{mV} \pm 2.22)$ among all the tested strains, which was a nearly 2-fold higher than that determined for Rt24.2. Also, the Rt2472 mutant producing considerably less EPS than the wild-type bacterium was characterized by a significantly higher relative zeta potential $(-52.9 \mathrm{mV} \pm 1.74)$ in comparison to the parental strain $(-63.5 \mathrm{mV} \pm 4.14)$. These data confirm that the lack or insufficient amounts of EPS significantly decrease the zeta potential of bacterial cells and affects their surface properties.

In order to determine the correlation between the amounts of produced EPS and the values of the zeta potential, we performed analysis, in which the relative zeta potential was calculated for 24-, 48-, and 96-h cultures of the Rt24.2 strain. In this experiment, it was found that the values of the relative zeta potential significantly decreased $(\mathrm{F}(2,24)=10.97 ; p<0.05)$ with an increase in the amount of EPS in the bacterial culture (Fig. 6). The linear correlation coefficient (r) for the analysed data was equal to 0.98 .

\section{Discussion}

Soil microorganisms are key drivers in soil functional processes including organic matter decomposition, turnover and release of nutrients, particularly nitrogen and phosphorus for subsequent plant capture (Vessey 2003; Hinsinger et al. 2009). Rhizobia belong to this group of ecologically important organisms. They are nitrogenfixing bacteria able to establish symbiosis with legume plants and providing them a nitrogen source, when they grow in soils deficient in this nutrient (Oldroyd et al. 2011; Janczarek et al. 2014). The process of biological nitrogen fixation is carried out in specialized structures, called nodules, which are formed on legume roots.
Successful infection of host roots is dependent on a reciprocal "molecular dialogue" between the plant and the microsymbiont, in which, among others, rhizobial exopolysaccharides secreted into the environment play an essential role (Broughton et al. 2003; Janczarek 2011). The first step of the infection process is attachment to and biofilm formation on host root surfaces (Downie 2010). Therefore, the adhesion ability of the rhizobial strains is a crucial feature for their effectiveness of host plant infection. R. leguminosarum bv. trifolii strains are able to establish a symbiotic interaction with clover plants (Trifolium spp.). We have indicated that the wild-type strain Rt24.2 producing large amounts of EPS had a high capability of attachment to roots of a compatible host plant as well as to abiotic surfaces (Figs. 3, 4 and 5). Also, growth conditions optimal for a maximal level of EPS synthesis were established for this bacterium (Figs. 1 and 2). In contrast to the wild-type Rt24.2, two mutant strains analysed in this work, in which the synthesis of EPS was significantly reduced (Rt2472rosR) or even totally blocked (Rt5819pssA), showed significantly decreased attachment to and biofilm formation on both biotic and abiotic surfaces, indicating that rhizobial EPS plays the essential role in these processes. This was especially visible in the case of the pssA mutant. Also, Williams et al. (2008) have indicated that the $R$. leguminosarum bv. viciae strain, having a mutation in a gene homologous to $R$. leguminosarum bv. trifolii pss $A$, formed immature biofilm on polystyrene plates, visible as a flat loosely attached lawn. Moreover, this mutant strain showed reduced attachment to root hairs of pea plants. On the other hand, the results of this study indicated that rhizobial strains Rt24.2(pBA1) and Rt24.2(pBR1), which overproduced EPS had a significantly increased ability to adhere to different surfaces, including soil particles and the host roots, which ensured better survival and adaptation to changing environmental conditions. Similarly in S. meliloti, EPS is required for biofilm development, since an exo $Y$ mutant non-producing this polymer forms an immature biofilm (Fujishige et al. 2006a; 2006b). In this bacterium, a symbiotically active low-molecular-weight fraction of galactoglucan proved to be crucial for biofilm formation and colonisation of host plant roots (Rinaudi and González 2009). Also, the degree of EPS polymerization is important for proper development of biofilms in rhizobia. Mutant strains of $R$. leguminosarum, having mutations in genes involved in EPS processing (prsD and prsE encoding 
Fig. 5 Attachment of the R. leguminosarum bv. trifolii strains to clover roots after $1 \mathrm{~h}$ and $48 \mathrm{~h}$ post inoculation. The data are mean $\pm \mathrm{SD}$ for three independent experiments conducted with the use of 10 seedlings per individual strain tested. Statistically significant differences $(p<0.05)$ observed between the strains after $1 \mathrm{~h}$ are marked with different upper case letters, whereas statistically significant differences $(p<0.05)$ observed after $48 \mathrm{~h}$ are marked with different lower case letters

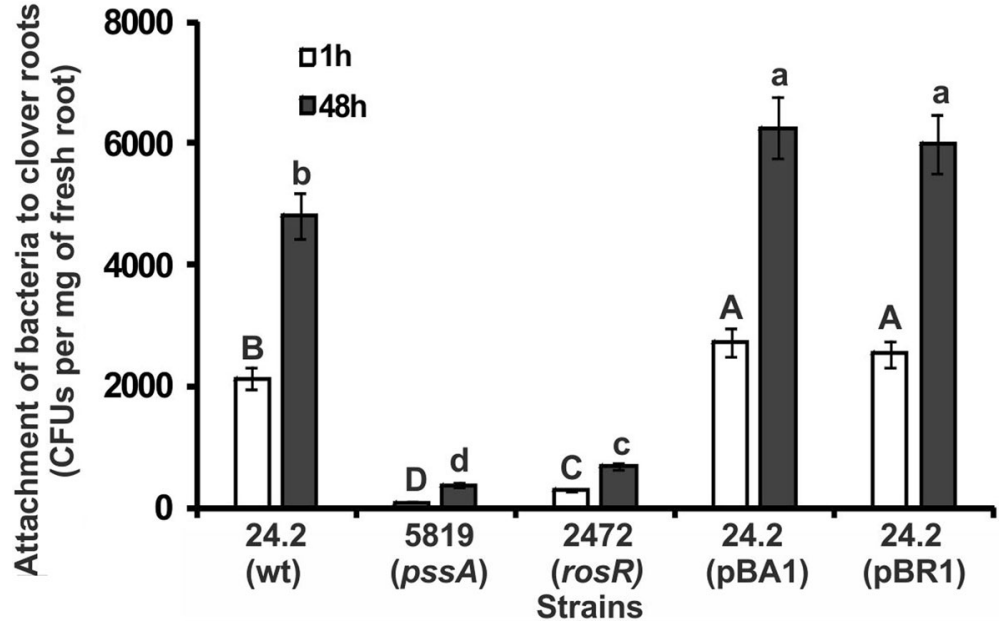

Apart from being a signal molecule in the early stages of the rhizobium-legume interactions, EPS is also a target site for plant lectins secreted by host roots and interacting with the sugar residues of rhizobial polysaccharides. Recently, Xie and co-workers (2012) have identified a plant arabinogalactan-like glycoprotein, which is engaged in a novel type of polar surface attachment by $R$. leguminosarum. This type of attachment required EPS and proved to be important for growth of these bacteria on the roots of both legumes and nonlegumes.

In this work, several environmental factors were tested and conditions optimal for both bacterial growth and EPS synthesis by $R$. leguminosarum bv. trifolii tion (Janczarek and Skorupska 2011).

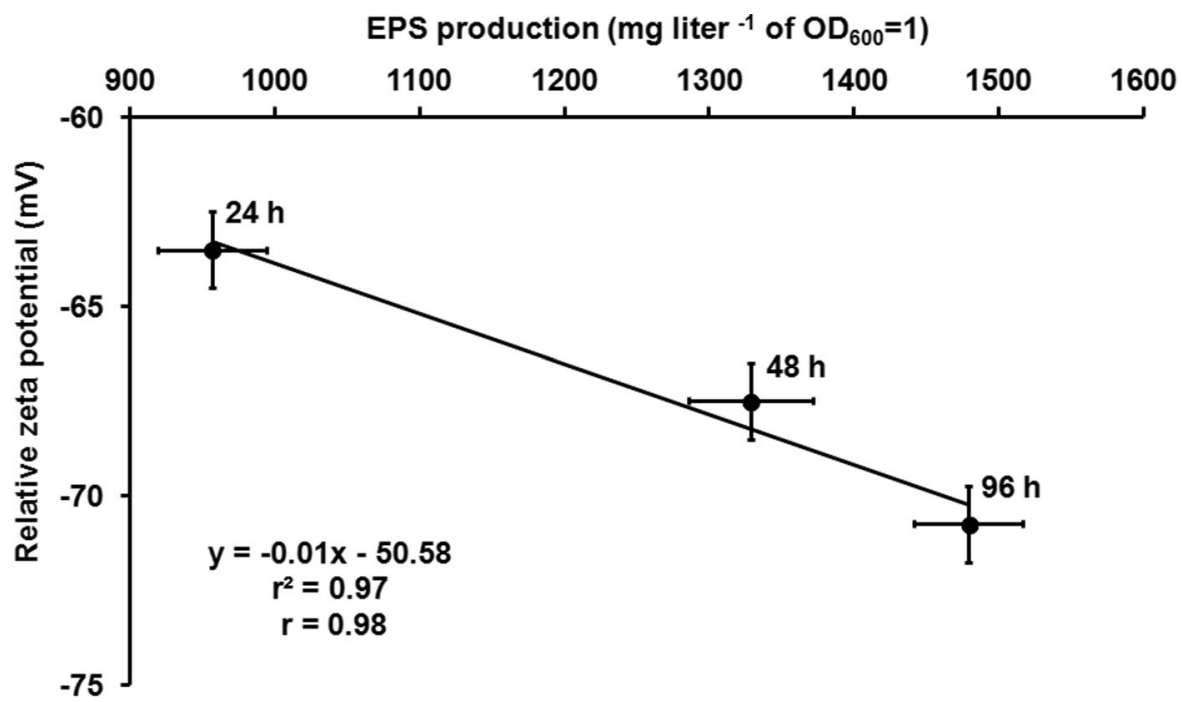

Fig. 6 The influence of the level of EPS produced by the Rt 24.2 strain on relative zeta potential values determined for 24,48 , and $96 \mathrm{~h}$ of the bacterial growth. In the figure is shown the trend line with its equation, coefficient of determination (r2) and coefficient of correlation (r) 
strain 24.2 were established (Figs. 1 and 2). We have tested 16 carbon sources, and among them glycerol, maltose, sucrose, and mannitol proved to be the best compounds for the bacterial growth. Considering the yield of EPS synthesis, the highest levels of production of this polysaccharide were detected when the Rt 24.2 strain grew in the presence of glycerol, sorbitol, and glucose. Among the tested compounds, glycerol proved to be the best carbon source for both the EPS synthesis and the growth of this strain. The results obtained for other carbon sources indicated that the level of the bacterial growth did not always correlate with the level of produced EPS. This was observed in the case of succinate, in the presence of which Rt24.2 grew very poorly but EPS synthesis exhibited a relatively high level (Fig. 1). We have found that other growth parameters such as time, temperature, $\mathrm{pH}$, and some cations also influenced the yields of EPS production. These findings are in agreement with the results for other rhizobial species, which showed that the levels of EPS synthesis were dependent on the type of the carbon source, culture time, $\mathrm{pH}$, temperature, and the shaking rate (Huang et al. 2012). Also, Quelas et al. (2006) described for Bradyrhizobium japonicum strain USDA 110 that culture conditions such as the type of the carbon source, nitrogen availability, and culture age can modify the amount of produced EPS. The authors tested mannitol and malate as carbon sources and indicated that the amount of synthesized EPS was higher in the presence of the former than the latter carbon source, whereas EPS composition was the same with both these carbon sources. In contrast, Karr et al. (2000) found for another B. japonicum strain 2143 that the type of the carbon source may also affect the composition of this polysaccharide. Similarly, Staudt et al. (2012) provided evidence for Rhizobium tropici CIAT899, indicating that the chemical composition of EPS can vary with changes to the growth environment. For example, EPS synthesized by this bacterium growing in the presence of glucose contained rhamnose-linked residues, which were not present when this bacterium grew in the presence of arabinose. Also for Rhizobium sullae, which nodulates Hedysarum coronarium plants, the influence of the carbon source on the production and the composition of EPS was observed (Gharzouli et al. 2013). All these data indicate that a change in the sugar composition of extracellular polysaccharides in response to the type of the carbon source may occur but it is not general and may be strain-specific. Another explanation of these observations could be the fact that, depending on the growth conditions and procedure of EPS isolation used, the fraction of extracellular polysaccharides could contain small amounts of other types of sugar polymers. For example, S. meliloti produces two types of EPS, succinoglycan and galactoglucan, depending on environmental conditions (Reuber and Walker 1993; Rüberg et al. 1999) and R. leguminosarum produces additional types of surface polysaccharides (neutral glucomannan and gel-forming polysaccharide) (Laus et al. 2006). This shows the complexity of the outer surface of rhizobial cells and suggests a complex regulatory network engaged in the synthesis of polysaccharides (Janczarek 2011; Geddes and Oresnik 2014).

In this study, surface properties of strains differing in the level of produced EPS were also characterized using the zeta potential. In our knowledge, this is the first work, in which the electrokinetic properties of rhizobial cells have been established in the context of EPS production and biofilm formation.

In our experiments, all the analysed strains possessed negative values of the relative electrokinetic potential. This was caused by domination of well-dissociated acidic functional groups (e.g., carboxyl, phosphoryl or sulfhydryl groups of carbohydrates and proteins) on the surface and the location of counterions far from the bacteria/liquid interface (Rutter and Vincent 1984; Wilson et al. 2001). In the case of $R$. leguminosarum bv. trifolii, sources of the net negative electrical charge of cells are mainly phosphoryl and 3-deoxy-D-mannooctulosonic acid (Kdo) carboxylate groups of lipopolysaccharide located in the outer bacterial membrane (Bushby 1990; Wilson et al. 2001). Also, other polysaccharides synthesized by rhizobia (e.g., EPS, gel-forming polysaccharide and glucomannan) could modify their surface charge and, in consequence, attachment to different materials, but this has not been investigated so far. Since $R$. leguminosarum bv. trifolii produces acidic EPS, which is secreted in large amounts outside bacterial cells and partially bound with them, it seems interesting to investigate if this polymer affects the surface charge of rhizobial cells (Janczarek 2011).

The data presented in this study confirmed the significant contribution of EPS in the electrokinetic potential of rhizobial cells, since the $p s s A$ mutant defective in the synthesis of this polysaccharide had a 2-fold lower value of the electrokinetic potential than the wild-type strain. Also, the ros $R$ mutant, in which EPS synthesis was reduced, possessed lower zeta potential than that of 
Rt24.2 but higher than of the pssA mutant. Similar results were reported by Planchon et al. (2013), who noticed that the Synechocystis cells, which had a greater EPS layer, exhibited more negative electrophoretic mobility (and thus zeta potential). Moreover, Jttawuttipoka et al. (2013) postulated that the zeta potential measurement could even facilitate finding EPS-defective mutants. Using the Rt24.2 strain, we have indicated a correlation between the amount of EPS present in the culture and the relative zeta potential value (Fig. 6).

In respect to bacterial attachment ability to different materials with a negative surface charge (Besra et al. 2000; Szatanik-Kloc et al. 2009), from the electrostatic point of view, the Rt5819 strain should be privileged. The barrier of electrostatic repulsion between the surface and the cells should be the lowest in this case (Rouissi et al. 2011; Dziubakiewicz and Buszewski 2014). However, the results presented in Figs. 4 and 5 showed that this strain poorly attached to both quartz and plant root surfaces. The most efficient attachment of bacteria to the abiotic and biotic surfaces was achieved by the $R$. leguminosarum strains which produced high amounts of EPS and exhibited the highest zeta potential values. This confirms that the electric surface properties of the bacteria and the interacting with them surface are important only in the short-time initial step of adhesion (Van Loosdrecht et al. 1989; 1990 and 1990a; Poortinga et al. 2002). Further, the presence of polymeric substances play a crucial role due to hydrophobic/ hydrophilic and steric interactions (Postma et al. 1991; Van Loosdrecht et al. 1989; 1990 and 1990a). Similar results were obtained by Postma et al. (1991), who observed that the higher the production of EPS and LPS in the strains, the more negative values of electrophoretic mobility, but the saccharide-non-producing strain attached to the glass surface more weakly than a control strain.

Apart from the electrical properties, many other factors should be considered in the interactions of bacterial cells with biotic and abiotic surfaces, including hydrophobic/hydrophilic properties, geometrical structures of both interacting materials as well as several surface polymers. Plant roots possess several components, which facilitate attachment of bacteria (e.g. arabinogalactan-like glycoprotein, lectins) (Laus et al. 2006; Xie et al. 2012). On the other hand, when both contacting surfaces are covered by polyelectrolytes, which possess an electrical charge, or both are coated by hydrophobic polymers, repulsive forces operate between them. Generally, the increase in the heterogeneity of surface charge distribution reduces repulsion during bacterial adhesion (Poortinga et al. 2002). Additionally, the contact of bacterial cells with such surfaces as soil particles can modify the electrokinetic properties of their envelopes (Bushby 1990). On the other hand, EPS could decrease the adherence of bacteria to hydrophilic surfaces by increasing their hydrophobicity (Habimana et al. 2014).

Our results indicate that EPS modified the electrokinetic properties of rhizobial cells and influenced attachment as well as biofilm formation. However, the EPS charge in the first (physicochemical) step of adhesion seems to have minor contribution, whereas the hydrophobic properties of this polysaccharide play a more dominant role in this process. In several papers, the role of EPS in early stages of symbiosis (infection of host plant roots) is well documented (Rolfe et al. 1996; Cheng and Walker 1998; Abreu et al. 2012; Janczarek and Rachwał 2013). Other authors confirmed that rhizobial EPS was required for attachment to inert substrates, and additional bacterial components (adhesins, glucomannan, cellulose fibrils) are engaged in the further steps of this process (Laus et al. 2006; Williams et al. 2008). Also, some environmental factors ( $\mathrm{pH}$ of soil, root exudates) affect bacterial attachment to host root hairs (Smit et al. 1989; Downie 2010).

\section{Conclusions}

The results of this work have shown that the ability of $R$. leguminosarum bv. trifolii strains to produce EPS significantly affects bacterial attachment, biofilm formation, and the zeta potential values of their cells. EPS produced by rhizobia facilitate adhesion of bacterial cells to both biotic and abiotic surfaces through hydrophobic interactions and heterogeneity of the envelope surface rather than electrostatic interactions, which in this case are strongly repulsive.

Acknowledgments This work was supported by the grant of the National Centre of Science no. DEC-2012/07/B/NZ1/00099 and the grant no. N303 092234. The microscopic analyses were done using Olympus SV1000 purchased from the funds of the project no. POPW.01.03.00-06-010/09-00 Operational Program Development of Eastern Poland 2007-2013, Priority Axis I, Modern Economy Operations 1.3 Innovations Promotion. 
Open Access This article is distributed under the terms of the Creative Commons Attribution License which permits any use, distribution, and reproduction in any medium, provided the original author(s) and the source are credited.

\section{References}

Abreu I, Cerda ME, Pérez de Nanclares M, Baena I, Lloret J, Bonilla I, Bolaños L, Reguera M (2012) Boron deficiency affects rhizobial cell surface polysaccharides important for suppression of plant defense mechanisms during legume recognition and for development of nitrogen-fixing symbiosis. Plant Soil 361:385-395

Becker A, Pühler A (1998) Specific amino acid substitutions in the proline-rich motif of the Rhizobium meliloti ExoP protein result in enhanced production of low-molecular-weight succinoglycan at the expense of high-molecular-weight succinoglycan. J Bacteriol 180:395-399

Besra L, Sengupta DK, Roy S (2000) Particle characteristics and their influence on dewatering of kaolin, calcite and quartz suspensions. Int J Miner Process 59:89-112

Beyenal H, Lewandowski Z, Harkin G (2004) Quantifying biofilm structure: facts and fiction. Biofouling 20:1-23

Breedveld MW, Zevenhuizen LPTM, Canter Cremers HCJ, Zehnder AJB (1993) Influence of growth conditions on production of capsular and extracellular polysaccharides by Rhizobium leguminosarum. Antonie van Leeuw 64:1-8

Broos K, Beyens H, Smolders E (2005) Survival of rhizobia in soil is sensitive to elevated zinc in the absence of the host plant. Soil Biol Biochem 37:753-579

Broughton WJ, Zhang F, Perre X, Staehelin C (2003) Signals exchanged between legumes and Rhizobium: agricultural uses and perspectives. Plant Soil 252:129-137

Brown CM, Dilworth MJ (1975) Ammonia assimilation by Rhizobium cultures and bacteroids. J Gen Microbiol 86:3948

Bushby HVA (1990) The role of bacterial surface charge in the ecology of root-nodule bacteria: an hypothesis. Soil Biol Biochem 22:1-9

Cheng HP, Walker GC (1998) Succinoglycan is required for initiation and elongation of infection threads during nodulation of alfalfa by Rhizobium meliloti. J Bacteriol 180:51835191

Cieśla J, Bieganowski A, Janczarek M, Urbanik-Sypniewska T (2011) Determination of the electrokinetic potential of Rhizobium leguminosarum bv. trifolii Rt24.2 using Laser Doppler Velocimetry - A methodological study. J Microbiol Meth 85:199-205

Delgado AV, Gonzales-Caballero F, Hunter RJ, Koopal LK, Lyklema J (2007) Measurement and interpretation of electrokinetic phenomena. J Colloid Interface Sci 309:194-224

Downie JA (2010) The roles of extracellular proteins, polysaccharides and signals in the interactions of rhizobia with legume roots. FEMS Microbiol Rev 34:150-170

Duodu S, Brophy C, Connolly J, Svenning MM (2009) Competitiveness of a native Rhizobium leguminosarum biovar trifolii strain for nodule occupancy is manifested during infection. Plant Soil 318:117-126
Dziubakiewicz E, Buszewski B (2014) Capillary electrophoresis of microbial aggregates. Electrophoresis 35:1160-1164

Fagerli IL, Svenning MM (2005) Arctic and subarctic soil populations of Rhizobium leguminosarum biovar trifolii nodulating three different clover species: characterisation by diversity at chromosomal and symbiosis loci. Plant Soil 275: 371-381

Fujishige NA, Kapadia NN, Hirsch AM (2006a) A feeling for the microorganism: structure on a small scale. Biofilms on plant roots. Bot J Linn Soc 150:79-88

Fujishige NA, Kapadia NN, De Hoff PL, Hirsch AM (2006b) Investigations of Rhizobium biofilm formation. FEMS Microbiol Ecol 56:195-206

Geddes B, Oresnik IJ (2014) Physiology, genetics, and biochemistry of carbon metabolism in the alphaproteobacterium Sinorhizobium meliloti. Can J Microbiol 60:491-507

Gharzouli R, Carpéné MA, Couderc F, Benguedouar A, Poinsot V (2013) Relevance of fucose-rich extracellular polysaccharides produced by Rhizobium sullae strains nodulating Hedysarum coronarium L. legumes. Appl Environ Microbiol 79:1764-1776

Habimana O, Semido AJC, Casey E (2014) The role of cellsurface interactions in bacterial initial adhesion and consequent biofilm formation on nanofiltration/reverse membranes. J Membr Sci 454:82-96

Hinsinger P, Bengough AG, Vetterlein D, Young IM (2009) Rhizosphere: biophysics, biogeochemistry and ecological relevance. Pant Soil 321:117-152

Huang KH, Chen BY, Shen FT, Young CC (2012) Optimization of exopolysaccharide production and diesel oil emulsifying properties in root nodulating bacteria. World J Microbiol Biotechnol 28:1367-1373

Ivashina T, Ksenzenko VN (2012) Exopolysaccharide Biosynthesis in Rhizobium leguminosarum: From Genes to Functions. In: The Complex World of Polysaccharides; InTech: Rijeka, Croatia, pp 99-127

Ivashina TV, Khmelnitsky MI, Shlyapnikov MG, Kanapin AA, Ksenzenko VN (1994) The pss4 gene from Rhizobium leguminosarum biovar viciae VF39: cloning, sequence and the possible role in polysaccharide production and nodule formation. Gene 50:111-116

Ivashina TV, Fedorova EE, Ashina NP, Kalinchuk NA, Druzhinina TN, Shashkov AS, Shibaev VN, Ksenzenko VN (2010) Mutation in the $p s s M$ gene encoding ketal pyruvate transferase leads to disruption of Rhizobium leguminosarum bv. viciaePisum sativum symbiosis. J Appl Microbiol 109:731-742

Janczarek M (2011) Environmental signals and regulatory pathways that influence exopolysaccharide production in rhizobia. Int J Mol Sci 12:7898-7933

Janczarek M, Rachwał K (2013) Mutation in the pss A gene involved in exopolysaccharide synthesis leads to several physiological and symbiotic defects in Rhizobium leguminosarum bv. trifolii. Int J Mol Sci 14:23711-23735

Janczarek M, Skorupska A (2011) Modulation of rosR expression and exopolysaccharide production in Rhizobium leguminosarum bv. trifolii by phosphate and clover root exudates. Int J Mol Sci 12:4132-4155

Janczarek M, Urbanik-Sypniewska T (2013) Expression of the Rhizobium leguminosarum bv. trifolii pssA gene involved in exopolysaccharide synthesis is regulated by RosR, phosphate and the carbon source. J Bacteriol 195:3412-3423 
Janczarek M, Jaroszuk-Ściseł J, Skorupska A (2009) Multiple copies of rosR and pssA genes enhance exopolysaccharide production, symbiotic competitiveness and clover nodulation in Rhizobium leguminosarum bv. trifolii. Antonie van Leeuw 96:471-486

Janczarek M, Rachwał K, Marzec A, Grządziel J, PalusińskaSzysz M (2014) Signal molecules and cell-surface components involved in early stages of the legume-rhizobium interactions. Appl Soil Ecol 85:94-113

Jaszek M, Janczarek M, Kuczynski K, Piersiak T, Grzywnowicz K (2014) The response of the Rhizobium leguminosarum bv. trifolii wild-type and exopolysaccharide-deficient mutants to oxidative stress. Plant Soil 376:75-94

Jttawuttipoka T, Planchon M, Spalla O, Benzerara K, Guyot F, Cassier-Chauvat C, Chauvat F (2013) Multidisciplinary evidences that Synechocystis PCC6803 exopolysaccharides operate in cell sedimentation and protection against salt and meta stress. PLoS ONE 8(2):e55564

Karr DB, Liang RT, Reuhs BL, Emerich DW (2000) Altered exopolysaccharides of Bradyrhizobium japonicum mutants correlate with impaired soybean lectin binding, but not with effective nodule formation. Planta 211:218-226

Koo H, Falsetta ML, Klein MI (2013) The exopolysaccharide matrix: a virulence determinant of cariogenic biofilm. J Dent Res 92:1065-1073

Laus MC, Logman TJ, Lamers GE, Van Brussel AA, Carlson RW, Kijne JW (2006) A novel polar surface polysaccharide from Rhizobium leguminosarum binds host plant lectin. Mol Microbiol 59:1704-1713

Lehman AP, Long SR (2013) Exopolysaccharides from Sinorhizobium meliloti can protect against $\mathrm{H}_{2} \mathrm{O}_{2}$-dependent damage. J Bacteriol 195:5362-5369

Leuko S, Legat A, Fendrihan S, Stan-Lotter H (2004) Evaluation of the LIVE/DEAD BacLight kit for extremophilic archaea and environmental hypersaline samples. Appl Environ Microbiol 70:6884-6886

Loewus FA (1952) Improvement in the anthrone method for determination of carbohydrates. Anal Chem 24:219-220

Martínez-Romero E (2003) Diversity of Rhizobium-Phaseolus vulgaris symbiosis: overview and perspectives. Plant Soil 252:11-23

O'Neill MA, Darvill AG, Albersheim P (1991) The degree of esterification and points of substitution by O-acetyl and O(3-hydroxybutanoyl) groups in the acidic extracellular polysaccharides secreted by Rhizobium leguminosarum biovars viciae, trifolii, and phaseoli are not related to host range. J Biol Chem 266:9549-9555

Oldroyd GE, Murray JD, Poole PS, Downie JA (2011) The rules of engagement in the legume-rhizobium symbiosis. Annu Rev Genet 14:119-144

Philip-Hollingsworth S, Hollingsworth RI, Dazzo FB (1989) Host-range related structural features of the acidic extracellular polysaccharides of Rhizobium trifolii and Rhizobium leguminosarum. J Biol Chem 264:1461-1466

Planchon M, Jittawuttipoka T, Cassier-Chauvat C, Guyot F, Chauvat F, Spalla O (2013) Influence of exopolysaccharides on the electrophoretic properties of the model cyanobacterium Synechocystis. Colloids Surf B 110:171-177

Ploux L, Beckendorff S, Nardin M, Neunlist S (2007) Quantitative and morphological analysis of biofilms formation on selfassembled monolayers. J Col Surf 57:174-181
Pollock TJ, Workum WA, Thorne L, Mikolajczak MJ, Yamazaki M, Kijne JW, Armentrout RW (1998) Assignment of biochemical functions to glycosyl transferase genes which are essential for biosynthesis of exopolysaccharides in Sphingomonas strain S88 and Rhizobium leguminosarum. J Bacteriol 180:586-593

Poortinga AT, Bos R, Norde W, Busscher HJ (2002) Electrical double layer interactions in bacterial adhesion to surfaces. Surf Sci Rep 47:1-32

Postma J, Hok-A-Hin CH, Schotman JMT, Wijffelman CA, van Veen JA (1991) Population dynamics of Rhizobium leguminosarum Tn5 mutants with altered cell surface properties introduced into sterile and non-sterile soils. Appl Environ Microbiol 57:649-654

Quelas JI, López-García SL, Casabuono A, Althabegoiti MJ, Mongiardini EJ, Pérez-Giménez J, Couto A, Lodeiro AR (2006) Effects of N-starvation and C-source on Bradyrhizobium japonicum exopolysaccharide production and composition, and bacterial infectivity to soybean roots. Arch Microbiol 186:119-128

Reuber TL, Walker GC (1993) Biosynthesis of succinoglycan, a symbiotically important exopolysaccharide of Rhizobium meliloti. Cell 74:269-280

Rinaudi LV, Giordano W (2010) An integrated view of biofilm formation in rhizobia. FEMS Microbiol Lett 304:1-11

Rinaudi LV, González JE (2009) The low-molecular-weight fraction of exopolysacccharide II from Sinorhizobium emliloti is a crucial determinant of biofilm formation. J Bacteriol 191: 7216-7224

Rinaudi L, Fujishige NA, Hirsch AM, Banchio E, Zorreguieta A, Giordano W (2006) Effects of nutritional and environmental conditions on Sinorhizobium meliloti biofilm formation. Res Microbiol 157:867-875

Robertsen BK, Aman P, Davill AG, McNeil M, Albersheim P (1981) Host-symbiont interactions. Plant Physiol 67:389-400

Rolfe BG, Carlson RW, Ridge RW, Dazzo RW, Mateos FB, Pankhurst CE (1996) Defective infection and nodulation of clovers by exopolysaccharide mutants of Rhizobium leguminosarum bv. trifolii. Aust J Plant Physiol 23: 285-303

Rouissi T, Tyagi RD, Brar SK, Provost D, John RP, Surampalli RY (2011) Efficient and simple method for determination of suspendibility of bio-inoculant suspensions. Bioresource Technol 102:10754-10758

Rüberg S, Pühler A, Becker A (1999) Biosynthesis of the exopolysaccharide galactoglucan in Sinorhizobium meliloti is subject to a complex control by the phosphate-dependent regulator PhoB and the proteins ExpG and MucR. Microbiology 145:603-11

Rudrappa T, Biedrzycki ML, Bais HP (2008) Causes and consequences of plant-associated biofilms. FEMS Microbiol Ecol 64:153-166

Russo DM, Williams A, Edwards A, Posadas DM, Finnie C, Dankert M, Downie JA, Zorreguieta A (2006) Proteins exported via the PrsD-PrsE type I secretion system and the acidic exopolysaccharide are involved in biofilm formation by Rhizobium leguminosarum. J Bacteriol 188:4474-4486

Rutter PR, Vincent B (1984) Physicochemical interactions of the substratum microorganisms and the fluid phase. In: Marshall KC (ed) Microbial Adhesion and Aggregation. SpringerVerlag AG, Berlin, pp 21-38 
Sambrook J, Fitsch EF, Maniatis T (1989) Molecular Cloning: A Laboratory Manual; Cold Spring Harbor Laboratory Press: Cold Spring Harbor, NY, USA

Smit G, Logman TJJ, Boerrigter ETI, Kijne JW, Lugtenberg BJJ (1989) Purification and partial characterization of the Rhizobium leguminosarum biovar viciae $\mathrm{Ca}^{2+}$-dependent adhesion, which mediates the first step in attachment of cells of the family Rhizobiaceae to plant root hair tips. J Bacteriol 171:4054-4062

Staudt AK, Wolfe LG, Shrout JD (2012) Variations in exopolysaccharide production by Rhizobium tropici. Arch Microbiol 194:197-206

Szatanik-Kloc A, Warchulska P, Józefaciuk G (2009) Changes in variable charge and acidity of rye (Secale cereale L.) roots surface under Zn-stress. Acta Physiolo Plant 31:59-64

Van Loosdrecht MCM, Lyklema J, Norde W, Zehnder AJB (1989) Bacterial adhesion: a physicochemical approach. Microbiol Ecol 17:1-15

Van Loosdrecht MCM, Lyklema J, Norde W, Zehnder AJB (1990a) Influence of interfaces on microbial activity. Microbiol Rev 54:75-87

Van Loosdrecht MCM, Norde W, Lyklema J, Zehnder AJB (1990b) Hydrophobic and electrostatic parameters in bacterial adhesion. Aquat Sci 52:103-114 van Workum WAT, van Slageren S, van Brussel AAN, Kijne JW (1998) Role of exopolysaccharides of Rhizobium leguminosarum bv. viciae as host plant-specific molecules required for infection thread formation during nodulation of Vicia sativa. Mol Plant Microbe Interact 11:1233-1241

Vessey JK (2003) Plant growth promoting rhizobacteria as fertilizers. Plant Soil 255:571-586

Vincent JM (1970) A manual for the Practical Study of Root Nodule Bacteria. In: International Biological Program Handbook no. 15; Blackwell Scientific Publications Ltd.: Oxford, UK

Williams A, Wilkinson A, Krehenbrink M, Russo DM, Zorreguieta M, Downie JA (2008) Glucomannan-mediated attachment of Rhizobium leguminosarum to pea root hairs is required for competitive nodule infection. J Bacteriol 190: 4706-4715

Wilson WW, Wade MM, Holman SC, Champlin FR (2001) Status of methods for assessing bacterial cell surface charge properties based on zeta potential measurements. J Microbiol Meth 43:153-164

Xie F, Williams A, Edwards A, Downie JA (2012) A plant arabinogalactan-like Glycoprotein promotes a novel type of polar surface attachment by Rhizobium leguminosarum. Mol Plant Microbe Interact 25:250-258 